\title{
Effect of high pH on the growth and survival of marine phytoplankton: implications for species succession
}

\author{
P. J. Hansen* \\ Marine Biological Laboratory, University of Copenhagen, Strandpromenaden 5, 3000 Helsingør, Denmark
}

\begin{abstract}
Ten years of $\mathrm{pH}$ measurements (1990 to 1999) in the surface waters of the eutrophic Mariager Fjord, Denmark, revealed profound seasonal variation. Typically, $\mathrm{pH}$ was relatively constant around 8 from January to March, increased during spring, reached maximum levels in July to August (9 to 9.7), and declined during autumn to about 8 in October. The influence of $\mathrm{pH}$ on the growth rate of phytoplankton was tested on 3 species (Ceratium lineatum, Heterocapsa triquetra and Prorocentrum minimum) in laboratory experiments. The growth rate was highest at $\mathrm{pH} 7.5$ to 8.0 in all species. The growth rate of $C$. lineatum declined by $\sim 20 \%$ at $\mathrm{pH} 8.3$ to 8.5 , while a similar reduction in the growth rate in $H$. triquetra and $P$. minimum was observed at $\mathrm{pH} 8.8$ to 8.9. C. lineatum stopped growing above $\mathrm{pH} 8.8$, while growth ceased at about $\mathrm{pH} 9.45$ in $H$. triquetra and 9.6 in P. minimum. Compilation of literature data on $\mathrm{pH}$ and phytoplankton growth suggested that while some species cannot grow at $\mathrm{pH} 8.4$, others are able to grow up to $\mathrm{pH} 10$. However, none of the species studied can attain their maximum growth rate above $\mathrm{pH} 9$. Competition experiments using a mixture of $C$. lineatum, $H$. triquetra and $P$. minimum always resulted in the species with the highest $\mathrm{pH}$ tolerance $(P$. minimum) outcompeting the other species, irrespective of the initial $\mathrm{pH}$ value. The role of high $\mathrm{pH}$ in the succession of marine phytoplankton in nature is discussed.
\end{abstract}

KEY WORDS: pH - Species succession - Competition - Marine - Phytoplankton · Growth · Inorganic carbon · DIC

\section{INTRODUCTION}

Uptake of inorganic carbon by phytoplankton during photosynthesis has the potential to increase $\mathrm{pH}$ in the surrounding water. However, while $\mathrm{pH}$ can rise above 10 in freshwater (e.g. Talling 1976), it is usually quite constant around 8.2 in surface seawaters. This is because seawater contains high concentrations ( $2 \mathrm{mM})$ of inorganic carbon, which buffers pH. Apart from some reports from natural environments (e.g. Hinga 1992, Macedo et al. 2001), high pH has usually been observed in marine enclosures after the addition of

\footnotetext{
*E-mail: pjhansen@zi.ku.dk

nutrients or in laboratory cultures of phytoplankton (Goldman 1982a,b, Hinga 1992). Although the occurrence of high $\mathrm{pH}$ in marine waters may not be uncommon, pH has generally not been considered an important determinant of pelagic processes, and papers dealing with the possible effect of $\mathrm{pH}$ on the growth and succession of marine phytoplankton are sparse. However, a few studies that have been carried out indicate that $\mathrm{pH}$ indeed may have an effect on phytoplankton growth and that this effect drives species succession (e.g. Goldman et al. 1982a,b, Schmidt \& Hansen 2001).

The present study was initiated in response to the observation of very high pH (up to 9.75) in the surface waters of Mariager Fjord, Denmark, during a summer 
bloom of the dinoflagellate Prorocentrum minimum in 1997 and to some recent results which have pointed to the fact that $\mathrm{pH}$ may be responsible for species succession (Schmidt \& Hansen 2001).

The first phase of this study was to collect data on the seasonal change in $\mathrm{pH}$ in the highly productive Mariager Fjord in order to describe the natural range of $\mathrm{pH}$ in a marine environment. The second phase aimed to study (1) the role of $\mathrm{pH}$ in limiting growth in laboratory cultures of marine phytoplankton and (2) the role of $\mathrm{pH}$ in the succession of species in mixed phytoplankton cultures in the laboratory.

\section{MATERIALS AND METHODS}

Seasonal and inter-annual variation in $\mathbf{p H}$ in a eutrophic fjord in Denmark. $\mathrm{pH}$ has been measured regularly during the past $20 \mathrm{yr}$ at a fixed station in Mariager Fjord, Denmark, by the counties of Aarhus and North Jutland as part of their monitoring program. The station is located at $56^{\circ} 39^{\prime} 80^{\prime \prime} \mathrm{N}, 9^{\circ} 58^{\prime} 69^{\prime \prime} \mathrm{E}$ close to the center of the deep basin, which has a water depth of $28 \mathrm{~m}$. The salinity in the surface water at this station varies from 16 to 17 ppt. For the past 10 yr measurements have been carried out weekly to bi-weekly, and these data were kindly provided by the counties. Data on $\mathrm{pH}$ are from the top part of the water column. Water, subsequently used for primary production, was gently poured into polyethylene bottles (2.5 l) to capacity to avoid aeration of the samples. The bottles were stored in the dark in a thermo-container until the measurement of $\mathrm{pH}$ shortly after, using a standard Radiometer $^{\circledR}$ glass $\mathrm{pH}$ electrode (sensitivity 0.01 ). The $\mathrm{pH}$ sensor was calibrated (2 point) using buffers of pH 7 and 10 .

Isolation and culture of phytoplankton. Information on isolation date, isolation place and clone designation of the 3 species of dinoflagellates used in the present study is listed in Table 1. The Scandinavian Culture Collection of Algae and Protozoa, Botanical Institute, University of Copenhagen, provided Heterocapsa triquetra and Prorocentrum minimum, while the Marine Biological Laboratory, University of Copenhagen, provided Ceratium lineatum. These species were chosen

Table 1. List of dinoflagellate species used in the experiments, their clone designation and isolation place and time

\begin{tabular}{|lll|}
\hline Species & Clone & Isolation place and time \\
\hline $\begin{array}{lll}\text { Ceratium lineatum } \\
\text { Heterocapsa triquetra }\end{array}$ & K-0481 & Øresund, Denmark, 1995 \\
Prorocentrum minimum & K-0295 & Kattegund, Denmark, 1988 \\
& & \\
\hline
\end{tabular}

based on previous experience concerning their different tolerance to $\mathrm{pH}$ in batch cultures. According to Schmidt \& Hansen (2001), C. lineatum should have a $\mathrm{pH}$ limit for growth at $\mathrm{pH} 8.79$, while the $\mathrm{pH}$ limits for growth of $H$. triquetra and $P$. minimum should be 9.43 and 9.62, respectively. The algae were grown as nonaxenic cultures in f/2 medium (Guillard 1983) based on seawater (30 psu) at $15 \pm 1^{\circ} \mathrm{C}$ following a light:dark cycle of $16: 8 \mathrm{~h}$. Illumination was provided by cool white fluorescent lamps, and cultures were kept at an irradiance of $25 \mu \mathrm{mol}$ photons $\mathrm{m}^{-2} \mathrm{~s}^{-1}$. Irradiance was measured using a LI-COR LI-1000 radiation sensor equipped with a spherical probe.

Experimental conditions. All experiments were carried out at an irradiance of $60 \mu \mathrm{mol}$ photons $\mathrm{m}^{-2} \mathrm{~s}^{-1}$. The dinoflagellates were adapted to this irradiance for at least $14 \mathrm{~d}$ prior to each experiment. Only cells from exponentially growing cultures were used for inoculation. For enumeration of cells, subsamples were fixed in acidic Lugol's iodine (2.5\% final concentration). Cells were counted in a Sedgewick-Rafter chamber or a multidish well $\left(\right.$ Nunclon $\left.{ }^{\circledR}\right)$. Growth rates $(\mu)$ were measured as increase in cell number and were calculated assuming exponential growth:

$$
\mu\left(\mathrm{d}^{-1}\right)=\frac{\left(\ln N_{1}-\ln N_{0}\right)}{t}
$$

$N_{0}$ and $N_{1}$ are number of cells at time $t_{0}$ and $t_{1}$, and $t$ is the difference in time (d) between $t_{0}$ and $t_{1}$ samples. All experiments were carried out in triplicate, and data from each triplicate were the mean of at least 3 growth rates (= 4 sampling dates). $\mathrm{pH}$ was measured using a Sentron ${ }^{\circledR}$ pH-meter (model 2001) equipped with Redline probe, which is an ISFET $^{\circledR}$ sensor (Semi-conductor Ion Field Effect Transistor) with a detection limit of 0.01 . The $\mathrm{pH}$ sensor was calibrated (2 point) using Sentron buffers of $\mathrm{pH} 7$ and 10.

Effect of $\mathbf{p H}$ on phytoplankton growth rate. The growth rates of the 3 dinoflagellates were measured at different $\mathrm{pH}$ within the range of 7.5 to 10 . The $\mathrm{pH}$ was adjusted by the addition of $0.1 \mathrm{M} \mathrm{NaOH}$ or $\mathrm{HCl}$. All experiments were carried out in Nunclon ${ }^{\circledR}$ tissue culture flasks $(250 \mathrm{ml})$, which were mounted on a plankton wheel $(1 \mathrm{rpm})$ in order to keep the phytoplankton in suspension. Each experiment was initiated by the inoculation of between 20 and 100 cells $\mathrm{ml}^{-1}$ and allowed to run for $7 \mathrm{~d}$. Daily, $\mathrm{pH}$ of the culture media was measured, and subsamples $(6 \mathrm{ml})$ were taken for enumeration of phytoplankton cells. After subsampling, the bottles were refilled to capacity with f/2 growth medium, which had the same $\mathrm{pH}$ as the respective experimental bottle. If the $\mathrm{pH}$ differed more than 0.03 from the 
set point, it was adjusted by addition of small amounts of $0.1 \mathrm{M} \mathrm{NaOH}$ or $\mathrm{HCl}$. The first $2 \mathrm{~d}$ of the experiments were considered an acclimation period; therefore cell counts from these samplings were not included in the calculations of growth rates. Also, the daily dilution (of $6 \mathrm{ml}$ ) was adjusted for in the calculations of algal growth rates.

Growth experiments with mixed phytoplankton cultures. Two types of succession experiments were carried out using the 3 dinoflagellates in mixture. In the first type of experiments, mixed cultures were initiated at $\mathrm{pH}$ levels of $8,8.5$, and 9.0. The $\mathrm{pH}$ was adjusted by the addition of $0.1 \mathrm{M} \mathrm{NaOH}$ or $\mathrm{HCl}$. All experiments were carried out in Nunclon ${ }^{\circledR}$ tissue culture flasks $(250 \mathrm{ml})$, which were mounted on a plankton wheel $(1 \mathrm{rpm})$ in order to keep the phytoplankton in suspension. The species were inoculated together at an initial concentration of $100 \mathrm{cells} \mathrm{ml}^{-1}$ of each species and allowed to grow. Every 2 to $3 \mathrm{~d}$, $\mathrm{pH}$ of the culture media was measured, and subsamples $(6 \mathrm{ml})$ were retrieved for enumeration of phytoplankton cells. Immediately after sampling, the bottles were refilled to capacity with f/2 growth medium, which had the same $\mathrm{pH}$ as the sampled medium.

Because the species Heterocapsa triquetra and Prorocentrum minimum have an almost similar tolerance to high $\mathrm{pH}$, a second type of experiment was carried out in order to exclude other possible effects, such as nutrient/vitamin limitation or effects of allelochemicals (toxins). This experiment was carried out in a 11 Pyrex flask containing $500 \mathrm{ml}$ of $\mathrm{f} / 2$ medium in triplicate. Atmospheric air was applied by bubbling in order to supply $\mathrm{CO}_{2}$ to the medium and thereby reduce the elevation of $\mathrm{pH}$, when cultures become dense. The species were inoculated together at an initial concentration of 100 cells ml $^{-1}$ of each species and allowed to grow. Every 2 to $3 \mathrm{~d}, \mathrm{pH}$ of the culture media was measured, and subsamples $(6 \mathrm{ml})$ were retrieved for enumeration of phytoplankton cells.

\section{RESULTS}

\section{pH in Mariager Fjord}

Median, minimum, and maximum $\mathrm{pH}$ values from $10 \mathrm{yr}$ of $\mathrm{pH}$ measurements (1990 to 1999) of surface water from the deep basin are shown in Fig. 1. The seasonal variation in $\mathrm{pH}$ was bell-shaped. From October to March, $\mathrm{pH}$ varied around 7.7 to 8.2. In April and May, $\mathrm{pH}$ increased rapidly to 8.7 . The highest $\mathrm{pH}$ was found in July and August ( $\mathrm{pH}$ 9). By August $\mathrm{pH}$ decreased again to reach $\mathrm{pH} 8$ in late September. The data also show that $\mathrm{pH}$ above 9 (max. 9.75) could be found at any time from May to August.

\section{pH limits for phytoplankton growth/survival in batch cultures}

The effect of $\mathrm{pH}$ on the growth rate was very profound in the 3 phytoplankton species Ceratium lineatum, Heterocapsa triquetra and Prorocentrum minimum (Fig. 2). The growth rate was highest at $\mathrm{pH} 7.5$ to 8.0 in all species. The growth rate of $C$. lineatum declined by $\sim 20 \%$ at $\mathrm{pH} 8.3$ to 8.5 , while a similar reduction in the growth rate in $H$. triquetra and $P$. minimum was achieved at $\mathrm{pH} 8.8$ to 8.9. C. lineatum stopped growing above $\mathrm{pH}$ 8.8, while growth ceased at about $\mathrm{pH} 9.45$ and 9.6 in $H$. triquetra and P. minimum, respectively

\section{Succession experiments in mixed phytoplankton batch cultures}

The importance of $\mathrm{pH}$ in the succession of phytoplankton species was studied using mixed cultures of the 3 species at 3 different initial $\mathrm{pH}$ levels: $8,8.5$, and 9 (Fig. 3). The experiments initiated at $\mathrm{pH} 8$ and 8.5 were quite similar. In both cases all species grew until $\mathrm{pH}$ reached 8.70 to 9 on Day 7. At Day 10 the $\mathrm{pH}$ had increased to above $\mathrm{pH}$ 9.4, and the entire population of Ceratium lineatum had died out. At Day 10 the growth of Heterocapsa triquetra also stopped, and during the following $2 \mathrm{wk}$ the concentration of $H$. triquetra declined. At Day 24 the entire population of $H$. triquetra had died out. The degradation of the $H$. triquetra population caused $\mathrm{pH}$ to decrease to 9 at Day 24 . Prorocentrum minimum was able to keep a positive growth rate until Day 17. During the period from

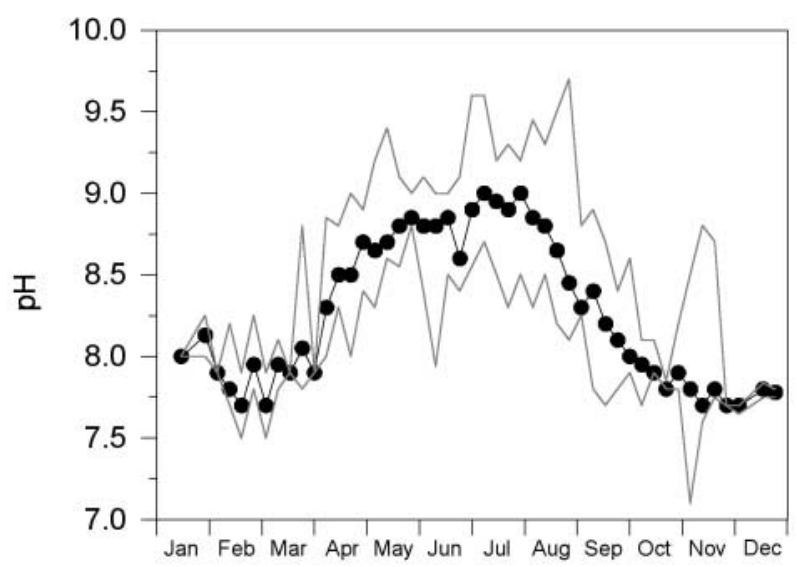

Fig. 1. Seasonal distribution of median $\mathrm{pH}(\bullet)$ in surface waters of Mariager Fjord, Denmark, for a 10 yr period (1990-1999). Maximum and minimum values are indicated with a solid grey line 

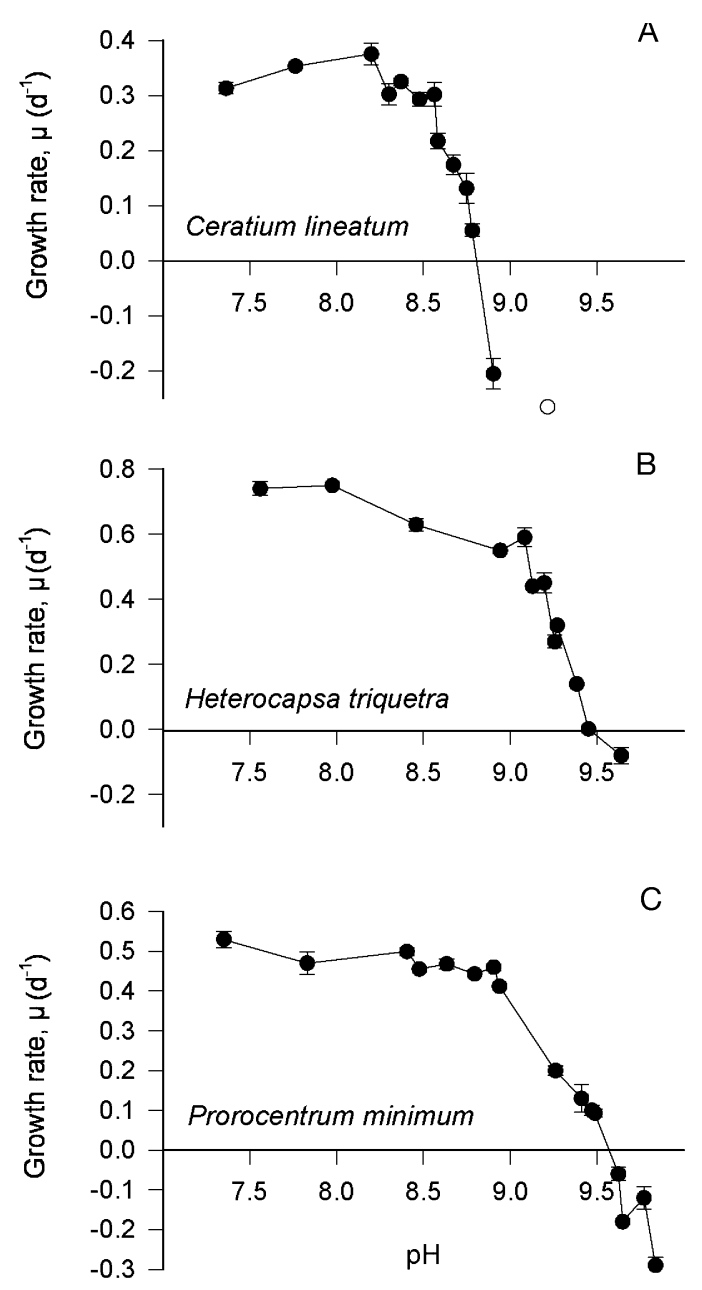

Fig. 2. Growth rate as a function of $\mathrm{pH}$ in laboratory cultures of (A) Ceratium lineatum, (B) Heterocapsa triquetra, and (C) Prorocentrum minimum. Data points refer to treatment means $\pm \mathrm{SE}(\mathrm{n}=3)$

Days 17 to 21, the $P$. minimum population just maintained itself, but after Day 21 it regained positive growth, resulting in an increase in $\mathrm{pH}$.

In the experiment initiated at $\mathrm{pH}$ 9, the Ceratium lineatum population died within the first $3 \mathrm{~d}$ of incubation, while Heterocapsa triquetra and Prorocentrum minimum grew until Days 14 and 19, respectively, when $\mathrm{pH}$ had increased to above 9.4 (Fig. 3E,F). The H. triquetra population declined from Day 16, and after $31 \mathrm{~d}$ of incubation had completely died out. In that period, $\mathrm{pH}$ decreased to below 9 . The $P$. minimum population maintained itself from Day 19 to Day 31, whereupon it increased again, resulting in an increase in $\mathrm{pH}$.

A control experiment was carried out in which bubbling with atmospheric air was applied to reduce the elevation of $\mathrm{pH}$ in a mixed culture of Heterocapsa triquetra and Prorocentrum minimum (Fig. 4). The $\mathrm{pH}$ in this experiment stayed fairly constant around 7.75 to 8 for the first $12 \mathrm{~d}$, whereupon it increased to reach about 9 on Day 17 and stayed at this level until the experiment was terminated. At this time the cell concentrations of $H$. triquetra and $P$. minimum had reached 185000 and 18500 cells ml $^{-1}$, respectively. In terms of total cell concentration, this was about 10 times higher than the cell concentration found in the experiment without bubbling initiated at $\mathrm{pH} 8$, and 20 times the cell concentration reached at the experiment initiated at $\mathrm{pH} 9$.

\section{DISCUSSION}

\section{High pH in marine waters}

A number of biological and physical processes may influence the $\mathrm{pH}$ of marine surface waters. Uptake of inorganic carbon by phytoplankton during photosynthesis may increase $\mathrm{pH}$, while release of $\mathrm{CO}_{2}$ through respiration processes will decrease $\mathrm{pH}$. Excursions of $\mathrm{pH}$ in marine waters are counteracted by the physical exchange of $\mathrm{CO}_{2}$ between the atmosphere and the surface water. Thus, the exchange of $\mathrm{CO}_{2}$ at the air-water transition is highly dependent on the vertical mixing of the water column, and thereby very much dependent on the strength of the wind stress and the stability of the water column.

In Mariager Fjord, the data from the past $10 \mathrm{yr}$ show a median $\mathrm{pH}$ of close to 9 during the summer (May to August). The maximum $\mathrm{pH}$ recorded within the past $10 \mathrm{yr}$ was 9.75 , which is close to the maximum $\mathrm{pH}$ that can be achieved in seawater. The development of such high $\mathrm{pH}$ values in Mariager Fjord is largely due to its high primary production and to its morphology and hydrography. The fjord is highly productive, and summer chlorophyll a concentrations may reach $>50 \mu \mathrm{g} \mathrm{l}^{-1}$ (Fenchel et al. 1995, Fallesen et al. 2000, Olesen 2001). The high productivity of the fjord is supported by inorganic nutrients draining from the surrounding farmland (Fallesen et al. 2000). The fjord has a sill and is permanently stratified with a salinity of 16 to $17 \mathrm{psu}$ in the top $10 \mathrm{~m}$. The water exchange of Mariager Fjord is relatively small, and the average residence time of water in the central part (above the $16 \mathrm{~m}$ ) is about $8 \mathrm{mo}$ (Fenchel et al. 1995, Fallesen et al. 2000). Thus, the combination of a stable water column, a low residence time of surface waters, high solar radiation during summer, and sufficient supply of nutrients form the physical basis for the development of phytoplankton blooms and high $\mathrm{pH}$ levels in Mariager Fjord.

Although the $\mathrm{pH}$ can become extremely high in Mariager Fjord, the fjord is not unique. In the 


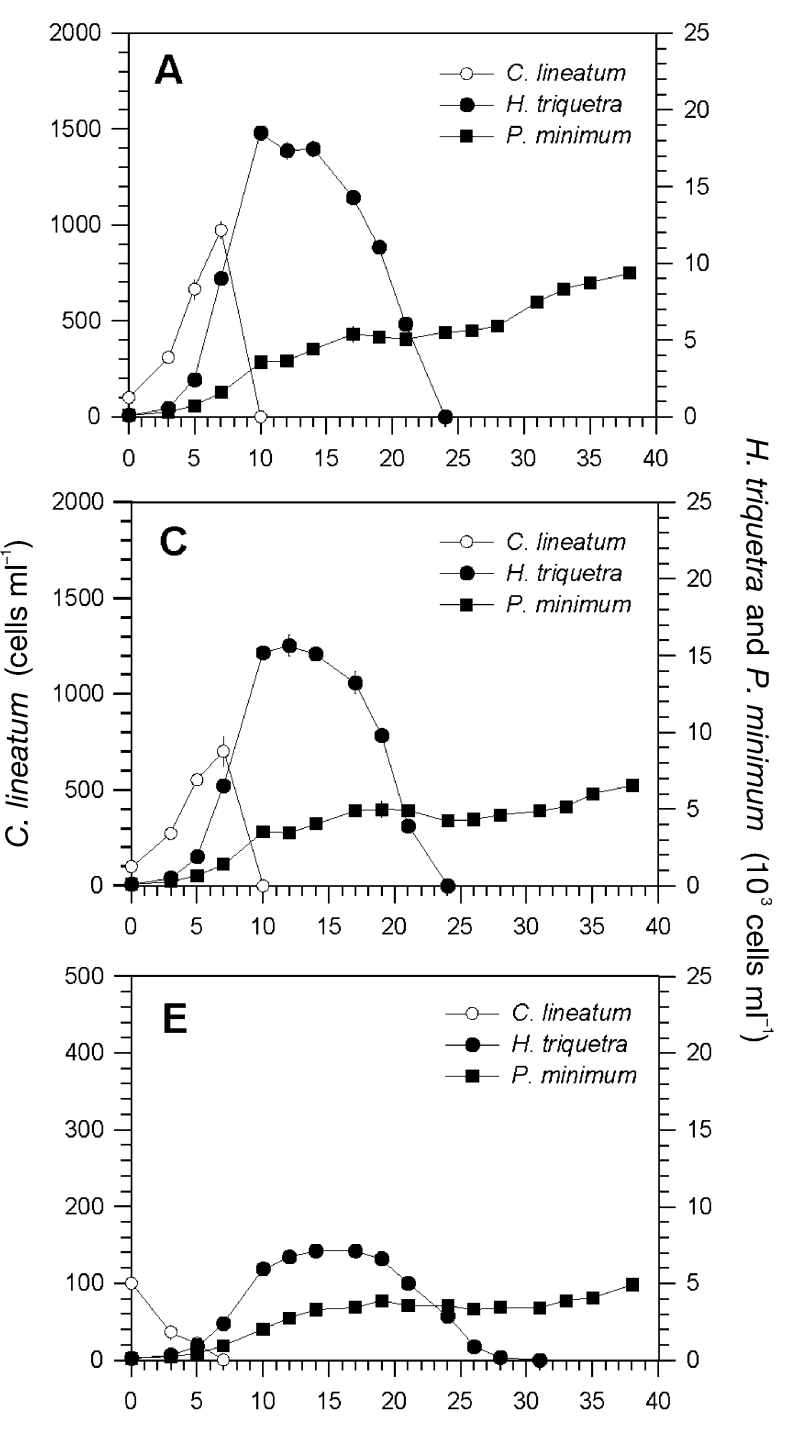

Time (d)
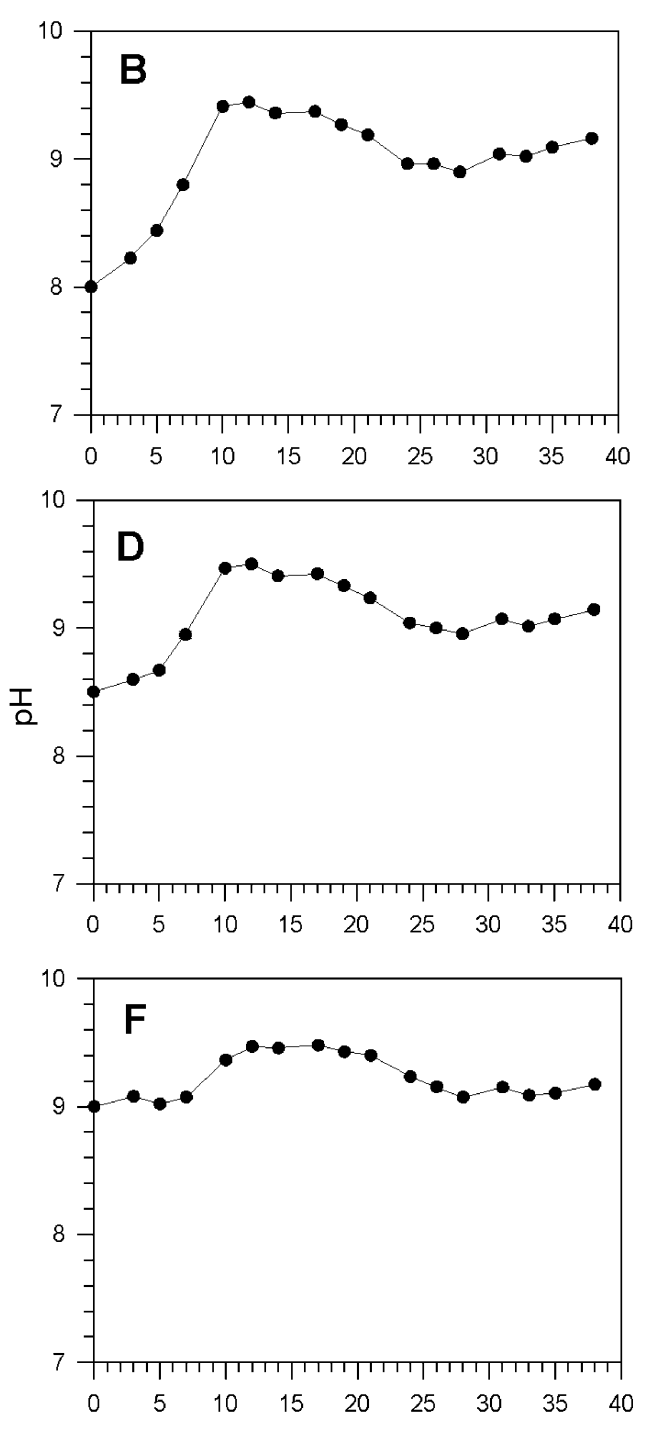

Time (d)

Fig. 3. Succession experiment. (A,,$E)$ Changes in cell concentration of the species Ceratium lineatum, Heterocapsa triquetra and Prorocentrum minimum as a function of time (d) from inoculation at 3 initial pH levels. (B,D,F) pH as a function of time from inoculation. Please note that the cell concentration of $C$. lineatum is shown on the left $y$-axes, while the cell concentration of the 2 other species is shown on the right $y$-axes

German Bight and in the Chesapeake Bay system, maximum $\mathrm{pH}$ of between 8.7 and 9.25 has been observed during the summer (e.g. Pegler \& Kempe 1988, Hinga 1992 and references therein). In enclosed lagoons that are only temporarily flooded, $\mathrm{pH}$ can reach values as high as 9.5 to 9.6 (Macedo et al. 2001). Thus, elevated pH may be a common phenomenon in the pelagial of many highly productive coastal waters and is a parameter that we should consider when dealing with phytoplankton production and species succession.

\section{Importance of $\mathrm{pH}$ for the growth of marine phytoplankton}

Chen \& Durbin (1994) studied the growth of 2 diatoms (Thalassiosira spp.) as a function of $\mathrm{pH}$ in the culture medium. Both diatoms were able to maintain their maximum growth rate up to $\mathrm{pH}$ 8.6. Above this $\mathrm{pH}$, the growth rate of the diatoms decreased to only ca. $10 \%$ of the maximum growth rate at $\mathrm{pH} 9.4$, resembling the $\mathrm{pH}$ dependency of the dinoflagellates Heterocapsa triquetra and Prorocentrum minimum in 

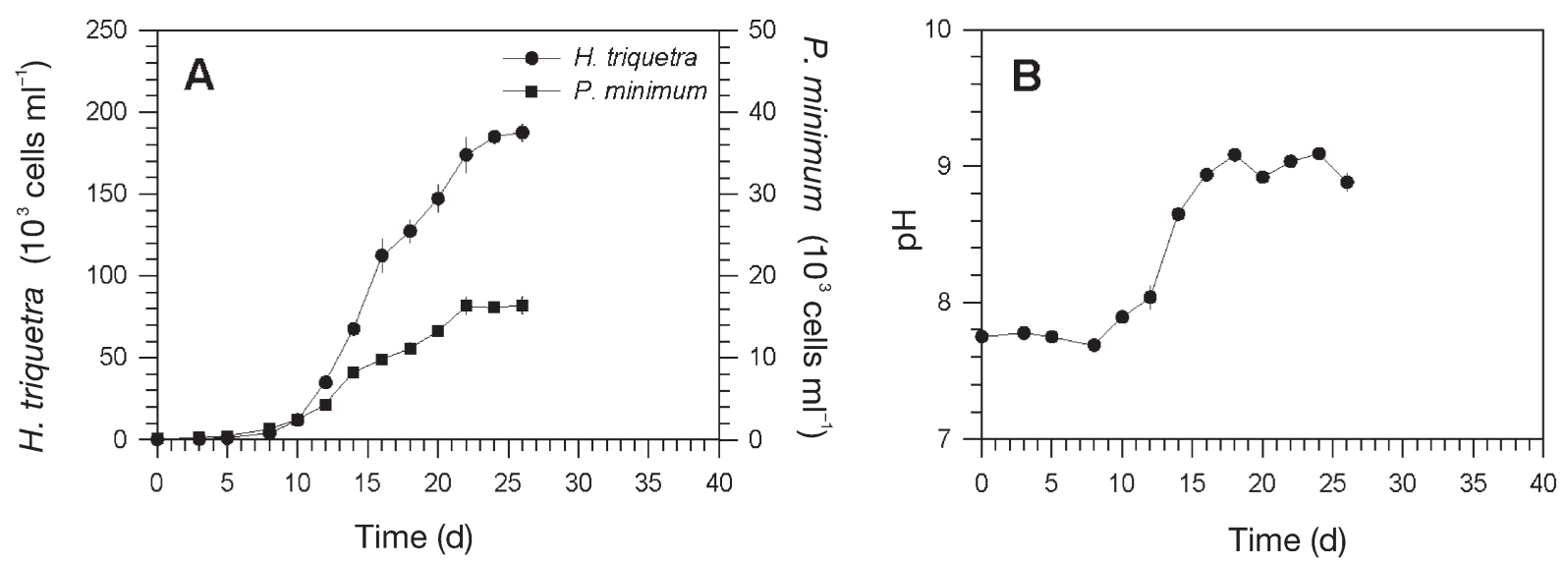

Fig. 4. Succession experiment-control experiment. (A) Changes in cell concentration of Heterocapsa triquetra and Prorocentrum minimum as a function of time from inoculation in mixed cultures, which were bubbled with atmospheric air to buffer $\mathrm{pH}$. (B) $\mathrm{pH}$ as a function of time from inoculation. Please note that the cell concentration of $H$. triquetra is shown on the left $y$-axes, while the cell concentration of $P$. minimum is shown on the right $y$-axes

the present study. Apart from the work by Chen \& Durbin (1994) and the present study, information on $\mathrm{pH}$ limits for the growth of marine phytoplankton comes from studies of batch cultures in which $\mathrm{pH}$ has not been kept constant.

The work of Schmidt \& Hansen (2001) suggested that marine phytoplankton cultures grown in a standard phytoplankton growth medium (like the f/2 growth medium) are limited by high $\mathrm{pH}$ rather than inorganic nutrients such as nitrogen and phosphorus. My data support this conclusion.

First, a simple calculation using the maximum concentrations of Ceratium lineatum, Heterocapsa triquetra and Prorocentrum minimum reached in $\mathrm{f} / 2$ medium (Schmidt \& Hansen 2001) and their cellular carbon content clearly suggests that such cultures are not nutrient-limited. In fact, the estimated uptake of nitrogen and phosphorus only accounted for about 5 to 11 and 7 to $17 \%$ of the available nitrogen and phosphorus, respectively (Table 2 ).

Table 2. Estimated uptake of $\mathrm{C}, \mathrm{N}$ and $\mathrm{P}$ in Ceratium lineatum, Heterocapsa triquetra and Prorocentrum minimum cultures that have reached maximum cell concentrations in $f / 2$ medium. Addition of $N$ and $P$ to the seawater in the $f / 2$ medium was 883 and $36 \mu \mathrm{M}$, respectively. Estimates were based on a red field ratio of $106 \mathrm{C}: 16 \mathrm{~N}: 1 \mathrm{P}$ (by mol). The carbon contents of the species were calculated from the carbon to cell volume equation published by Strathmann (1967)

\begin{tabular}{|lcccc|}
\hline Species & $\begin{array}{c}\text { Maximum cell } \\
\text { concentration } \\
\left(\text { cells ml }{ }^{-1}\right)\end{array}$ & $\begin{array}{c}\text { C uptake } \\
(\mu \mathrm{M})\end{array}$ & $\begin{array}{c}\text { N uptake } \\
(\mu \mathrm{M})\end{array}$ & $\begin{array}{c}\text { P uptake } \\
(\mu \mathrm{M})\end{array}$ \\
\hline Ceratium lineatum & $4.0 \times 10^{3}$ & 280 & 42.3 & 2.64 \\
Heterocapsa triquetra & $4.0 \times 10^{4}$ & 639 & 96.6 & 6.03 \\
Prorocentrum minimum & $5.5 \times 10^{4}$ & 652 & 98.3 & 6.15 \\
\hline
\end{tabular}

Second, the $\mathrm{pH}$ at which the 3 selected dinoflagellates just maintained themselves in the constant $\mathrm{pH}$ experiment at low cell concentrations in the present study was similar to the $\mathrm{pH}$ obtained in the stationary growth phase of the same species in enriched batch cultures (cf. Table 3 with Fig. 2). Likewise, the pH causing a reduction in growth rates of the 3 studied species by $20 \%$ in the present study was similar to the pH causing a ca. $20 \%$ reduction of the growth rate in ordinary batch cultures (cf. Table 3 with Fig. 2).

Thus, in the absence of data from experiments carried out at constant $\mathrm{pH}$ levels, data on $\mathrm{pH}$ limits for maximum growth rate (reduction ca. $20 \%$ ) as well as the $\mathrm{pH}$ limits for growth for marine phytoplankton can be obtained from ordinary batch culture experiments (Table 3). Comparison of literature data on 35 species of marine phytoplankton suggested a great variation in their tolerance to high $\mathrm{pH}$. Some species (Ceratium tripos, C. furca) stopped growing at a $\mathrm{pH}$ above 8.3 to 8.4, while others were able to grow at a $\mathrm{pH}$ close to 10 (e.g. Phaeodactylum tricornutum, Rhodomonas salina). It is notable that within the same family some species were sensitive while others were insensitive to high $\mathrm{pH}$ (e.g. dinoflagellates and diatoms). When the number of phytoplankton species capable of growing at a specific $\mathrm{pH}$ was plotted as a function of $\mathrm{pH}$, the data fitted a 1tailed normal distribution (Fig. 5). Only half of the species investigated could sustain growth at $\mathrm{pH}$ above 9.2.

For 17 species, data were also available on the $\mathrm{pH}$ at which maximum growth was reduced by $20 \%$. While 
the growth of some species was affected at $\mathrm{pH}$ below 8.4, other species could maintain their maximum growth at $\mathrm{pH} 9$. However, none of the tested species could grow at their maximum growth rate much above pH 9. Thus, although Rhodomonas salina or Prorocentrum minimum could grow at $\mathrm{pH}$ close to 10 , their growth rates were already affected at a $\mathrm{pH}$ of 9 to 9.1 . It is also noteworthy that only half of the species investigated reached maximum growth rates at $\mathrm{pH}$ between 8.6 and 8.8. Therefore $\mathrm{pH}$ should be taken into account when dealing with phytoplankton growth in the laboratory and in natural environments.

Several reasons for the effects of high $\mathrm{pH}$ on the growth of phytoplankton may be suggested. Changes of $\mathrm{pH}$ in seawater influence the inter-speciation of inorganic carbon (as $\mathrm{CO}_{2}$ aq., $\mathrm{HCO}_{3}{ }^{-}, \mathrm{CO}_{3}{ }^{2-}$ ). In seawater at $\mathrm{pH} 8$, ca. $1 \%$ of DIC is present as $\mathrm{CO}_{2}$, while at $\mathrm{pH} 9$ only ca. $0.1 \%$ of the DIC is available in this form. Limitation in the supply of $\mathrm{CO}_{2}$ caused by elevated $\mathrm{pH}$ may therefore potentially restrict photosynthesis and growth in marine phytoplankton. However, at least some phytoplankton species have active transport systems by which they can take up $\mathrm{HCO}_{3}{ }^{-}$in order to avoid DIC limitation at elevated pH (e.g. Colman \& Gehl 1983, Dixon \& Merrett 1988, Colman \& Rotatore 1995, Korb et al. 1997, Huertas et al. 2000). Thus, elevated $\mathrm{pH}$ should favour species which can utilize $\mathrm{HCO}_{3}{ }^{-}$as an inorganic carbon source. Alternatively, high extracellular $\mathrm{pH}$ may cause gross alterations in the membrane transport processes and metabolic

Table 3. $\mathrm{pH}$ limits for exponential growth and for positive growth $(\mu=0)$ in highly enriched batch cultures for phytoplankton belonging to a variety of taxa. Salinity was in all cases between 30 and $34 \mathrm{psu}$. Taxa abbreviations refer to eumastigohytes (Eumast.), cryptophytes (Cryp.), dinoflagellates (Dino.), prymnesiophytes (Prym.), raphidophytes (Raphid.), silicoflagellates (Silico.), prasinophytes (Prasino.), chlorophytes (Chloro.). ${ }^{*}$ Criterion: growth is affected when growth rate is reduced by $>20 \%$

\begin{tabular}{|c|c|c|c|c|}
\hline Species & Taxon & $\begin{array}{c}\mathrm{pH} \text { limits for } \\
\text { exponential growth* }\end{array}$ & $\begin{array}{l}\mathrm{pH} \text { limits for growth } \\
\qquad(\mu=0)\end{array}$ & Source \\
\hline Phaeodactylum tricornutum & Diatom & & $>10 ; 10.3 ; 10.4$ & $1,2,3$ \\
\hline Amphidinium carterae & Dino. & & $>10$ & 1 \\
\hline Nanochloropsis sp. & Eumast. & & 10.08 & 4 \\
\hline Rhodomonas marina & Crypt. & 8.74 & 9.93 & 5 \\
\hline Prorocentrum micans & Dino. & 8.75 & 9.92 & 5 \\
\hline Thalassiosira pseudonana & Diatom & & 9.77 & 4 \\
\hline Prorocentrum minimum & Dino & 9.20 & 9.62 & 5 \\
\hline Dunaliella tertiolecta & Chloro. & & $8.69 ; 9.5$ & 4,1 \\
\hline Nitzschia closterium & Diatom & & 9.5 & 1 \\
\hline Nitzschia sp. & Diatom & & 9.5 & 1 \\
\hline Heterocapsa triquetra & Dino & $8.80 ; 8.90$ & 9.43 & 5 \\
\hline Synechococcus sp. & Cyano. & & 9.40 & 4 \\
\hline Chroomonas sp. & Crypto. & & 9.3 & 1 \\
\hline Emiliania huxleyi (heavy coccoliths) & Prym. & & 9.29 & 4 \\
\hline Chrysochromulina simplex & Prym. & 9.20 & 9.25 & 5 \\
\hline Eutrieptiella gymnastica & Eugl. & 9.00 & 9.22 & 5 \\
\hline Skeletonema costatum & Diatom & 8.49 & 9.21 & 5 \\
\hline Chrysochromulina polylepis & Prym. & 8.70 & 9.20 & 5 \\
\hline Heterosigma akashiwo & Raphid. & 8.52 & 9.15 & 5 \\
\hline Phaeocystis globosa & Prym. & & 9.14 & 4 \\
\hline Biddulphia aurita & Diatom & & 9 & 1 \\
\hline Chaetoceros didymus & Diatom & & 9 & 1 \\
\hline Gymnodinium splendens & Dino. & & 9 & 1 \\
\hline Monochrysis lutheri & Prym. & & 9 & 1 \\
\hline Gymnodinium mikimotoi & Dino. & 8.72 & 9.00 & 5 \\
\hline Alexandrium ostenfeldii (2 clones) & Dino. & 8.66 & 8.90 & 5 \\
\hline Thalassiosira punctigera & Diatom & & 8.90 & 4 \\
\hline Alexandrium tamarense & Dino. & 8.66 & 8.85 & 5 \\
\hline Dictyocha speculum & Silicofl. & 8.30 & 8.81 & 5 \\
\hline Emiliana huxleyi (weak coccoliths) & Prym. & & 8.80 & 4 \\
\hline Pyramimonas propulsa & Prasino. & 8.55 & 8.80 & 5 \\
\hline Ceratium lineatum & Dino. & 8.30 & 8.79 & 5 \\
\hline Cylindrotheca closterium & Diatom & & 8.5 & 1 \\
\hline Ceratium furca & Dino. & 8.29 & 8.40 & 5 \\
\hline Ceratium tripos & Dino. & 8.24 & 8.30 & 5 \\
\hline
\end{tabular}



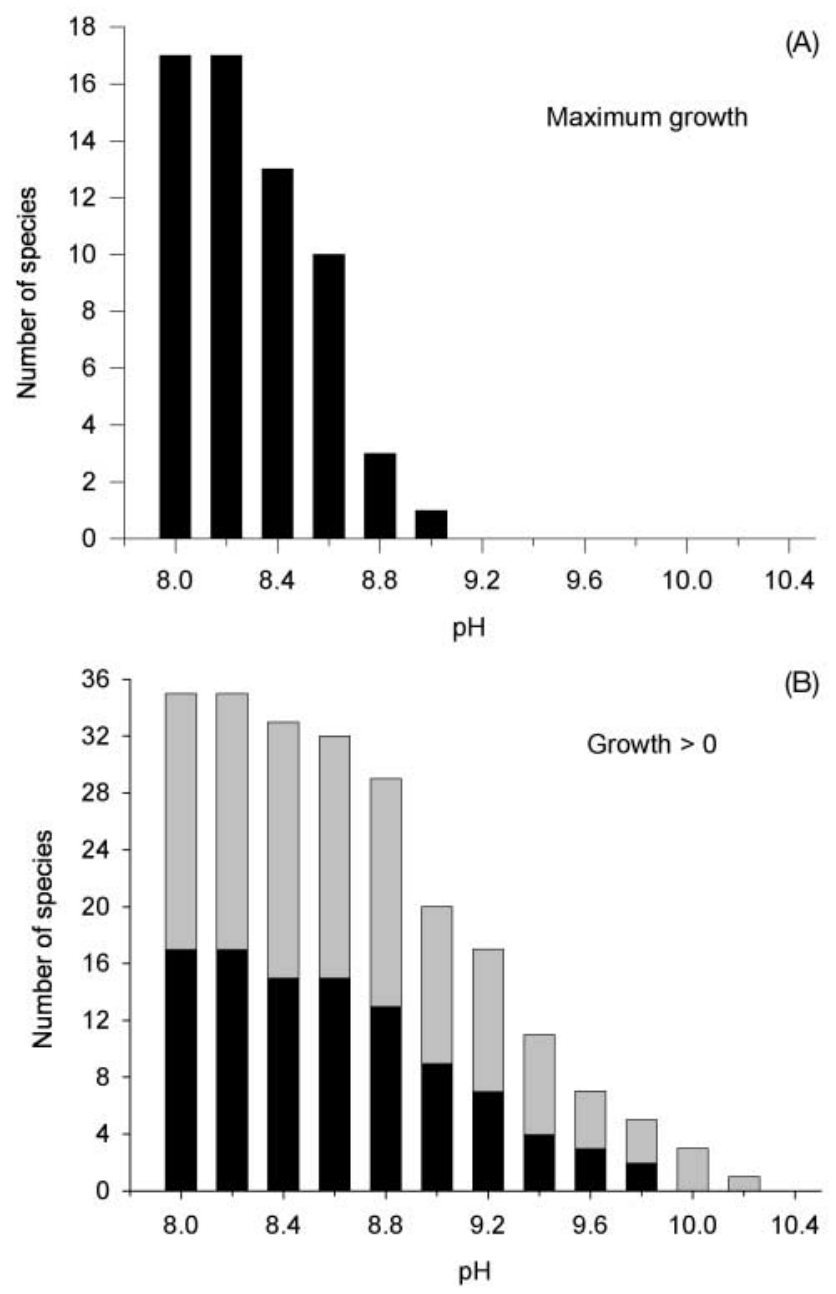

Fig. 5. pH limits of marine phytoplankton obtained in batch cultures. (A) $\mathrm{pH}$ at which the growth rate is reduced by $>20 \%$. (B) $\mathrm{pH}$ obtained in stationary growth phase. Data collected from the literature (Table 3 ). The black bars refer to data from Schmidt \& Hansen (2001)

functions involved in internal $\mathrm{pH}$ regulation (Smith \& Raven 1979, Raven 1980, 1993) or cause changes in cellular content of amino acids and their relative composition, possibly affecting cellular growth (e.g. Taraldsvik \& Myklestad 2000).

\section{Species succession}

Although there are many studies on species succession in multi-species phytoplankton batch cultures, only a few have taken $\mathrm{pH}$ into account (see reviews by Maestrini \& Bonin 1982a,b). The possible role of high $\mathrm{pH}$ in the succession of phytoplankton species was first addressed by Goldman et al. (1982a,b). They observed that the diatom Phaeodactylum tricornutum often suc- cessfully invaded other phytoplankton cultures in the laboratory. Through a set of competition experiments they demonstrated that $P$. tricornutum out-competed Dunaliella tertiolecta in continuous cultures when $\mathrm{pH}$ exceeded 9.2.

The role of high $\mathrm{pH}$ in species succession among marine phytoplankton was studied here by exposing 3 species in mixture to different initial $\mathrm{pH}$ values between 8 and 9 (Fig. 3). Irrespective of the initial pH, Prorocentrum minimum always outcompeted the 2 other species. Ceratium lineatum died out soon after the $\mathrm{pH}$ had exceeded 8.7, independently of the initial $\mathrm{pH}$, which is in accordance with the results obtained for this species in the monoculture experiments at fixed $\mathrm{pH}$ levels (Fig. 2A). Heterocapsa triquetra grew in the mixture experiments until $\mathrm{pH}$ exceeded 9.4 (Fig. 3), which again is in accordance with the results obtained in the monoculture experiments at fixed $\mathrm{pH}$ levels (Fig. 2B).

Prorocentrum minimum has a $\mathrm{pH}$ limit for growth, which is only slightly higher than that of Heterocapsa triquetra, and thus other factors such as nutrient/vitamin limitation or production of allelochemicals (toxins) may have been involved in the interaction between these 2 species in the mixture experiment.

Earlier in this section (when discussing the importance of $\mathrm{pH}$ for growth of marine phytoplankton) a rough calculation suggested that nitrogen and phosphorus are not limiting the growth of either Heterocapsa triquetra or Prorocentrum minimum in f/2 growth medium. The results obtained in the aerated mixture experiment support that suggestion and also exclude vitamin limitation, because total cell yield in the aerated mixture experiment was at least 10 times higher than in the non-aerated mixture experiment (Figs. 3 \& 4). Also, the maximum cell yield in the non-aerated mixture experiment decreased when the initial $\mathrm{pH}$ set point was elevated. Thus, any kind of nutrient/vitamin limitation can be ruled out as the cause of the species succession in these experiments.

A few studies have indicated that some isolates of Prorocentrum minimum can produce toxic substances (Trick et al. 1981, Grzebyk et al. 1997). In laboratory cultures, these toxins appear to be produced only during the stationary growth phase. In the present study no clear indications of negative effects due to $P$. minimum toxins on the other algae could be found. However, because $P$. minimum has a $\mathrm{pH}$ limit for growth which is only slightly higher than that of Heterocapsa triquetra, it cannot be completely ruled out that toxins exuded by $P$. minimum may have contributed to the decline of the $H$. triquetra population in the non-buffered mixture experiments (Fig. 3). Nevertheless, it seems justified to suggest that 
elevated $\mathrm{pH}$ alone can drive a species succession among marine phytoplankton.

Very few data are available on the occurrence of the 3 studied species in relation to high $\mathrm{pH}$ in nature. However, in Mariager Fjord the dinoflagellates Heterocapsa triquetra and Prorocentrum minimum usually form almost mono-specific blooms during summer periods (Fenchel 1995, Fallesen et al. 2000, Olesen 2001), in which $\mathrm{pH}$ is extremely high $(\mathrm{pH}>9.2$, this data set). Similar observations have been made in the coastal Santo André Lagoon, SW Portugal (Macedo et al. 2001), where almost mono-specific blooms of $P$. minimum co-occur with $\mathrm{pH}$ of 9.5 to 9.6. It is noteworthy that the $\mathrm{pH}$-sensitive Ceratium species are completely lacking in both Mariager Fjord and Santo André Lagoon (Fenchel et al. 1995, Macedo et al. 2001, Olesen 2001), although Ceratium spp. are common in waters just outside these areas (e.g. Taylor \& Pollingher 1987).

It is evident from the compiled data on $\mathrm{pH}$ limits for marine phytoplankton growth that the ability to tolerate high $\mathrm{pH}$ is not related to any particular algal groups, but rather is species-specific (Table 3). A few studies have indicated that $\mathrm{pH}$ in nature in fact may be associated with certain groups of phytoplankton. Yoo et al. (1991) performed a correlation analysis between dinoflagellate abundance and environmental parameters in Masan Bay, Korea, which suggested that $\mathrm{pH}$ was the main factor influencing dinoflagellate abundance. Hinga (1992) found that high abundance of dinoflagellates was strongly correlated with high $\mathrm{pH}$, whereas high abundance of diatoms was not. Similarly, in the Santo André Lagoon, blooms of dinoflagellates (Prorocentrum) have co-occurred with $\mathrm{pH}$ of 9.5 to 9.6 (Macedo et al. 2001). At slightly lower $\mathrm{pH}$ (<9.1 to 9.4), the phytoplankton community in this lagoon was more diverse, and other phytoplankton groups co-dominated. Thus, although a few reports suggest that mainly dinoflagellates are associated with extremely high $\mathrm{pH}$ in nature, our knowledge on the topic is still very limited, and other groups of algae, especially bloom-forming species, may in the future indeed be found to be associated with high $\mathrm{pH}$.

\section{CONCLUSIONS}

$\mathrm{pH}$ can rise to very high levels in eutrophic estuaries, lagoons and embayments during summers with high insolation and calm weather. In such environments, $\mathrm{pH}$ changes may drive species succession of phytoplankton and impede primary production, because many species are quite sensitive to high $\mathrm{pH}$. The reason for the growth reductions of phytoplankton at high $\mathrm{pH}$ needs yet to be assessed.
Acknowledgements. I thank the counties of Northern Jutland and Aarhus for allowing me to use their data on $\mathrm{pH}$ from Mariager Fjord. I am indebted Marina Madsen, Bo Sørensen and Lena Malmberg for technical assistance. I would like to thank Kaj Sand-Jensen for his constructive criticism of and suggestions for the manuscript. The work was funded by both the Danish Natural Research Council project no. 9801391 and the European Commissions Environment \& Sustainable Development (ESD), (FP-V, Research into the Development of Sustainable Marine Ecosystems, Key Action 3) under contract EVK3-CT-1999-00015 BIOHAB (Biological Control of Harmful Algal Blooms in European Coastal Waters).

\section{LITERATURE CITED}

Chen CY, Durbin EG (1994) Effects of pH on the growth and carbon uptake of marine phytoplankton. Mar Ecol Prog Ser 109:83-94

Colman B, Gehl K (1983) Physiological characteristics of photosynthesis in Porphyridium cruentum: evidence for bicarbonate transport in a unicellular red alga. J Phycol 19:216-219

Colman B, Rotatore C (1995) Photosynthetic inorganic carbon uptake and accumulation in two marine diatoms. Plant Cell Environ 18:919-924

Dixon GK, Merrett MJ (1988) Bicarbonate utilization by the marine diatom Phaeodactylum tricornutum Bohlin. New Phytol 109:47-51

Elzenga JTM, Prins HBA (2000) The role of extracellular carbonic anhydrase activity in inorganic utilization of Phaeocystis globosa (Prymnesiophyceae): a comparison with other marine algae using the isotopic disequilibrium technique. Limnol Oceanogr 45:372-380

Fallesen G, Andersen F, Larsen B (2000) Life, death and revival of the hypertrophic Mariager Fjord, Denmark. J Mar Syst 25:313-321

Fenchel T, Bernard C, Esteban G, Finlay B, Hansen PJ, Iversen N (1995) Microbial diversity and activity in a Danish Fjord with anoxic deep water. Ophelia 43:45-100

Goldman JC, Azov Y, Riley CB, Dennett MR (1982a) The effect of $\mathrm{pH}$ in intensive microalgal cultures. I. Biomass regulation. J Exp Mar Biol Ecol 57:1-13

Goldman JC, Riley CB, Dennett MR (1982b) The effect of pH in intensive microalgal cultures. II. Species competition. J Exp Mar Biol Ecol 57:15-24

Grzebyk D, Denardou A, Berland B, Pouchus YF (1997) Evidence of a new toxin in the red-tide dinoflagellate Prorocentrum minimum. J Plankton Res 19:1111-1124

Guillard RRL (1983) Culture of phytoplankton for feeding invertebrate animals. In: Berg CJ (ed) Culture of marine invertebrates. Hutchinson Ross Publishing, Stroudsberg, PA, p 123-128

Hinga KR (1992) Co-occurrence of dinoflagellate blooms and high $\mathrm{pH}$ in marine enclosures. Mar Ecol Prog Ser 86: 181-187

Huertas IE, Colman B, Espie GS, Lubian LM (2000) Active transport of $\mathrm{CO}_{2}$ by three species of marine microalgae. J Phycol 36:314-320

Humphrey GF (1975) The photosynthesis: respiration ratio of some unicellular marine algae. J Exp Mar Biol Ecol 18: 111-119

Korb RE, Saville PJ, Johnston AM, Raven J (1997) Sources of inorganic carbon for photosynthesis by three species of marine diatoms. J Phycol 33:433-440

Macedo, MF, Duarte P, Mendes P, Ferreira JG (2001) Annual variation of environmental variables, phytoplankton spe- 
cies composition and photosynthetic parameters in a coastal lagoon. J Plankton Res 23:719-732

Maestrini SY, Bonin DJ (1981a) Competition among phytoplankton based on inorganic macronutrients. In: Platt $\mathrm{T}$ (ed) Physiological bases of phytoplankton ecology. Can Bull Fish Aquat Sci 210:264-278

Maestrini SY, Bonin DJ (1981b) Allelopathic relationships between phytoplankton species. In: Platt T (ed) Physiological bases of phytoplankton ecology. Can Bull Fish Aquat Sci 210:323-338

Nimer NA, Iglesias-Rodriguez MD, Merrett MJ (1997) Bicarbonate utilization by marine phytoplankton species. J Phycol 33:625-631

Olesen M (2001) Sedimentation in Mariager Fjord, Denmark: the impact of sinking velocity on system productivity. Ophelia 55:11-26

Pegler K, Kempe S (1988) The carbonate system of the North Sea: determination of alkalinity and $\mathrm{TCO}_{2}$ and calculation of $\mathrm{PCO}_{2}$ and Sical (spring 1986). Mitt Geol Paläont Inst Univ Hamb 65:35-87

Raven J (1980) Nutrient transport in microalgae. Adv Microbiol Physiol 21:47-226

Raven J (1993) Limits on growth rate. Nature 361:209-210

Schmidt LE, Hansen PJ (2001) Allelopathy in the prymnesio-

Editorial responsibility: David Caron,

Los Angeles, California, USA phyte Chrysochromulina polylepis: effect of cell concentration, growth phase and pH. Mar Ecol Prog Ser 216:67-81

Smith FA, Raven R (1979) Intracellular pH and its regulation. Annu Rev Plant Physiol 30:289-311

Strathmann RR (1967) Estimating the organic carbon content of phytoplankton from cell volume or plasma volume. Limnol Oceanogr 12:411-418

Talling JF (1976) The depletion of carbon dioxide from lake water by phytoplankton. J Ecol 64:79-121

Taraldsvik M, Myklestad SM (2000) The effect of pH on the growth rate, biochemical composition and extracellular carbohydrate production of the marine diatom Skeletonema costatum. Eur J Phycol 35:189-194

Taylor FJR, Pollingher U (1987) Ecology of dinoflagellates. In: Taylor FJR (ed) The biology of dinoflagellates. Botanical monographs, Vol 21. Blackwell Scientific Publications, Oxford, p 399-529

Trick CG, Harrison PJ, Andersen RJ (1981) Extracellular secondary metabolite production by the marine dinoflagellate Prorocentrum minimum in culture. Can J Fish Aquat Sci 38:864-867

Yoo KI (1991) Population dynamics of dinoflagellate community in Masan Bay with a note on the impact of environmental parameters. Mar Pollut Bull 23:185-188

Submitted: January 2, 2002; Accepted: April 22, 2002

Proofs received from author(s): June 27, 2002 